\title{
The influence of logistics integration on information sharing and business performance: The case of small and medium enterprises in South Africa
}

\author{
Authors: \\ Richard Chinomona ${ }^{1}$ \\ R.I. David Pooe ${ }^{1}$ \\ Affiliations: \\ ${ }^{1}$ Department of Logistics, \\ Vaal University of \\ Technology, South Africa \\ Correspondence to: \\ Richard Chinomona \\ Email: \\ rchinos@hotmail.com \\ Postal address: \\ Department of Logistics, Vaal \\ University of Technology, \\ Private Bag X021, \\ Vanderbijlpark 1900, \\ South Africa \\ Dates: \\ Received: 04 Mar. 2013 \\ Accepted: 20 Aug. 2013 \\ Published: 29 Oct. 2013 \\ How to cite this article: \\ Chinomona, R. \& Pooe, \\ R.I.D., 2013, 'The influence \\ of logistics integration on \\ information sharing and \\ business performance: The \\ case of small and medium \\ enterprises in South Africa', \\ Journal of Transport and \\ Supply Chain Management \\ 7(1), Art. \#92, 9 pages. \\ http://dx.doi.org/10.4102/ \\ jtscm.v7i1.92

\section{Copyright:} \\ C 2013. The Authors. \\ Licensee: AOSIS \\ OpenJournals. This work \\ is licensed under the \\ Creative Commons \\ Attribution License. \\ Read online:

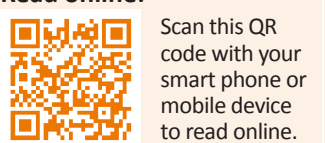

Logistics integration across partnering firms has become the backbone of supply chain management as it facilitates information sharing, which is required in order to enhance business performance. This study investigated the mediatory role of information sharing on the relationships between logistics integration and business performance within the small and medium enterprise (SME) context. Five research hypotheses were postulated and the hypotheses were empirically tested using sample data from the SME sector in South Africa's Gauteng Province. The results indicated that logistics integration positively influences information sharing and business performance in a significant way within the context of South African SMEs. Managerial implications of the findings are discussed, whilst limitations and future research directions are indicated.

\section{Introduction}

A cross examination of the extant supply chain management empirical studies indicates that the literature is replete with research. This highlights the over-riding influence of logistics integration on business or supply chain performance (Lai, Wong \& Cheng 2010). Drawing from the literature, both academicians and practitioners agree that today's successful firms are those that know how important it is to adapt to the demands of logistics integration (Gelinas \& Bigras 2004). There is general consensus within the literature that without the efficient and effective integration of logistics activities, the increasingly recognised value in supply chains will be difficult to attain (Chen \& Paulraj 2004; Bagchi \& Skjoett-Larsen 2003; Daugherty, Ellinger \& Gustin 1996). Furthermore, in supply chain management literature, logistics integration is considered to be one of the important precursors to financial and business performance (Louw \& Venter 2006; Lai et al. 2010). This is because logistics integration leads to a reduction in operational costs and an improvement in customer services (Richardson 1995; Ballou 2007; Lai, Ngai \& Cheng 2004; Ambe 2012). The integration of logistics activities within other functional areas may enable an enterprise to realise the full potential of its value-added activities and, hence, to gain a significant competitive advantage (Rutner \& Langley 2000; Coyle, Bradi \& Langley 2003; Louw \& Venter 2006).

Logistics is the process of planning, implementing and controlling the efficient cost-effective flow and storage of raw materials, in-process inventory, finished goods and related information from the point of origin to the point of consumption for the purpose of satisfying the customers' requirements (Renko \& Ficko 2010). Pagel (2004) defined integration as the extent to which separate parties work together in a cooperative manner to arrive at mutually acceptable outcomes. Logistics integration therefore refers to a process of interaction and collaboration in which separate parties work together in a cooperative manner to arrive at mutually acceptable outcomes for their organisations (Renko \& Ficko 2010). Thus, logistics integration brings together inter-dependent entities into a cohesive system in order to attain a high degree of cooperation, coordination, interaction and collaboration (Premus \& Sanders 2010). According to Gélinas and Bigras (2004), logistics integration helps increase the speed and fluidity of physical and information flows, helps synchronise demand with supply and helps manage transactions more accurately.

Despite the recognised importance of logistics integration in the supply chain management literature, most studies discussed the matter from the perspective of large firms (Prajogo \& Olhager 2012; Gimenez 2006; Häkkinen et al. 2004). Studies that focus on small and medium enterprises (SMEs) logistics integration and business performance have largely remained scant. However, there has been some research conducted on SME characteristics and logistics integration in Australia, such as one by Gélinas and Bigras (2004). It is reported that SMEs are a vehicle for employment generation and that they also contribute significantly towards economic growth 
in developing countries (Chinomona \& Pretorius 2011). Given this fact, it is important to examine this issue within the South African SME context. Further to that, most of the studies largely focused on the relationship between: logistics integration and supply chain performance (Kim 2006; Lee, Kwon \& Severance 2007; Green Jr., Whitten \& Inram 2008); logistics technologies and customer value (Renko \& Ficko 2010); information technology and logistics integration (Lai et al. 2010; Choi, Narasimhan \& Kim 2011). However, there remains a deficiency of studies that investigate the mediatory influence of information sharing within the logistics integration and business performance relationship within the South African SME context - a research subject that is largely neglected by many supply chain management researchers.

Based on this identified research gap, the main purposes of the current study were two-fold. Firstly, within the context of SMEs in the Gauteng Province of South Africa, this study sought to investigate the influence of logistics integration on business information sharing and performance. Secondly, this study intended to explore the extent to which information sharing has a mediatory effect on the logistics integration and business performance relationship within the SME context. It was hoped that the current study would make academic and practical contributions to the existing SMEs logistics integration literature and practice within the African context.

\section{Literature review}

\section{Small and medium enterprises in South Africa}

According the 1996 National Small Business Act of South Africa, an SME is:

\begin{abstract}
A separate and distinct entity including cooperative enterprises and non-governmental organisations managed by one owner or more, including its branches or subsidiaries if any is predominantly carried out in any sector or sub-sector of the economy mentioned in column 1 of the schedule and which can be classified as a micro-, a very small, a small or a medium enterprise by satisfying the criteria mentioned in columns 3,4 and 5 of the schedule opposite the smallest relevant size or class as mentioned in column 2 of the Schedule. (Republic of South Africa 2003)
\end{abstract}

The differentiating factor between these categories, excluding microenterprises, is the number of employees.

The assertion that SMEs are drivers of economic growth is indisputable (Fatoki \& Garwe 2010; Chinomona \& Pretorius 2011). Academics, policy makers, economists and business owners all agree that a healthy SME sector prominently contributes to the economy by: creating more employment opportunities; generating higher production volumes; increasing exports; and introducing innovation and entrepreneurial skills (Chinomona, Lin, Wang \& Cheng 2010; Chinomona 2012). According to Fatoki and Garwe (2010), SMEs are the first vital step towards industrialisation. Also supporting the same notion, Chinomona and Cheng (2013) asserted that one of the significant characteristics of a flourishing and growing economy is a vibrant and blooming SME sector. Whilst the contributions of SMEs in the South African economy are undisputed, it is interesting that the different authors vary in their estimation of such contributions. For example, the Department of Trade and Industry (2008) reported that between 2004 and 2007 the percentage of SMEs grew to represent $34 \%$ of all active business in the economy. The report further states that the medium-sized enterprises accounted for the highest growth. Abor and Quartey (2010) estimated that 91\% of the formal business entities in South Africa are SMEs, they contribute between $52 \%$ and $57 \%$ of the GDP and they account for approximately $61 \%$ of employment in South Africa (Erasmus \& Mathunjwa 2011).

\section{Information sharing}

The goal of developing boundary-free organisations (Welch, Bossidy \& Hood 1990) has seen information sharing playing a paramount role in logistics integration. However, such endeavour requires businesses to: review the way in which information circulates internally; reconsider the role of their commercial partners as sources of information relevant to the decision making process; rethink their information processing and management tools. Amongst a number of identified information sharing-related success factors for integration are: electronic data interchange (Arminas 1999); automation; computerisation and precision of productionrelated information (Ansari, Lockwood \& Modarress 1999); material requirement planning (MRP); computerisation of stock management and precision of stock-related information (Richardson 1999); and information quality in general. Compared to large businesses, the use of information technologies for logistics information sharing has been minimal; this is mainly due to the financial limitations of SMEs. However, there is growing evidence indicating that the adoption of information technologies by SMEs in order to foster their business information sharing is on the increase. This evidence also shows that the size of the SME and the priorities of the owner-manager influence the SME information technology development and information sharing.

\section{Logistics integration}

According to O'Leary-Kelly and Flores (2002), integration refers to the extent to which separate parties work together in a cooperative manner to arrive at mutually acceptable outcomes. In the current study, logistics integration encompasses the degree of cooperation, coordination, interaction and collaboration between SMEs' logistics activities. Thus, this study defines logistics integration as a process of inter-business interaction and collaboration in which manufacturing, purchasing and logistics work together in a cooperative manner in order to arrive at mutually acceptable outcomes for their businesses. It is important that businesses know how to adapt to the demands of logistics integration (Rutner \& Langley 2000) in order to adjust to the needs of their customers, to preserve their market shares and to assure their growth. According to Chen and Paulraj (2004), logistics integration is an essential and indispensable element of supply chain management, 
and without it, value creation might be hard to attain (Lai et al. 2004). This is because logistics integration provides a significant competitive advantage (Louw \& Venter 2006), leads to a reduction in operational costs and an improvement in customer services, which eventually leads to improved business performance (Lai et al. 2010).

\section{Small business performance}

According to Kathuria (2000), business performance in a supply chain is influenced by the reliability, competence and cooperation of other chain members. This implies that supplier quality, flexibility, delivery, cost performance and prompt response have a potential bearing on a business enterprise's performance (Shin et al. 2000). Even though financial performance has been widely used in the extant literature to measure business performance, some researchers have considered operational performance indicators such as different aspects of time-based performance in various stages of the overall value-delivery cycle (Jayaram et al. 1999). The proposed time-based performance includes: delivery speed (Handfield \& Pannesi 1992); new product development time (Vickery et al. 1995); delivery reliability or dependability (Roth \& Miller 1990; Handfield 1995); new product introduction (Safizadeh et al. 1996); manufacturing lead-time (Handfield \& Pannesi 1995); and customer responsiveness (Hendrick 1994). In order to measure business performance, many researchers have recently adopted a market performance measure that defines a broader conceptualisation of business performance and focuses on factors that ultimately lead to financial performance (Vorhies \& Morgan 2005). In view of these different performance measurements, the current study adopts a market-performance measure epitomised by sales, growth and market share (Homburg \& Pflesser 2003; Hooley et al. 2005; Wong \& Merrilees 2007) to measure small business performance.

\section{Conceptual model and hypothesis development}

Drawing from the literature review and the postulated hypotheses, a conceptual model was developed (Figure 1). The model consists of three research variables: one predictor - SME logistics integration; one mediator - SME information sharing; and one outcome variable - SME business performance.

SME logistics integration and information sharing: Due to the value creation through links between members of a chain, logistics integration has gained considerable attention in supply chain management literature (Sahin \& Robinson 2005). The supply chain literature reveals that effective linkage of various logistics activities amongst supply chain members is critical for facilitating the coordination of information flows from supplier to manufacturer and customer, as well as the backward flow from customer to manufacturer and supplier (Quesada et al. 2008). There is consensus in the literature that higher levels of logistics integration lead to increased synchronisation of logistics activities, effective and efficient flow of information and consequently improved information sharing (Zhou \& Banton 2007). Similarly, the current study submits that logistics integration leverages the flow of timely, accurate and quality information and eventually leads to improved information sharing between SMEs and other supply chain members. Previous studies conducted on large size firms have also found a positive relationship between logistics integration and information sharing (Sahin \& Robinson 2005); hence, SMEs logistics integration can be expected to increase the intensity of information sharing in South Africa. Therefore, it can be hypothesised that:

Hypothesis 1: SMEs logistics integration positively influences their information sharing.

SME logistics integration and business performance: Logistics integration facilitates profit maximisation and eventually leads to improved business performance (Olhager \& Prajogo 2012). The arguments presented are that logistics integration improves competitive advantage, lowers transaction costs, enhances flexibility, reduces inventories, eliminates the bullwhip effect, improves delivery quality and shortens cycle times (Kannan \& Tan 2005). In addition, logistics integration enables a centralised approach of management across the extended value network consisting of various parties (Zailani \& Rajagopal 2005). Through centralisation of operations, management and strategic decisions, the unified control of processes and actors undertakes the role of maximising utilisation of assets both internally and externally (Van der Vaart \& Van Donk 2008). Consequently, business performance improves (Flynn, Huo \& Zhao 2010). Accordingly, an SME's ability to effectively integrate its logistics activities with its suppliers or customers can provide a source of enduring competitive advantage (Cusumano \& Yoffie 1998) and, eventually, superior business performance (Van der Vaart \& Van Donk 2008). Therefore, this study submits that high levels of SMEs logistics integration with their suppliers and customers are likely to lead to their superior business performance through the transfer of realtime, reliable, accurate information both across supply chain partners externally and within the functions of individual organisation. Prior evidence from large firms has also found a positive relationship between logistics integration and business performance (Kim 2006, 2009; Olhager \& Prajogo 2012). Thus, this study seeks to determine this relationship

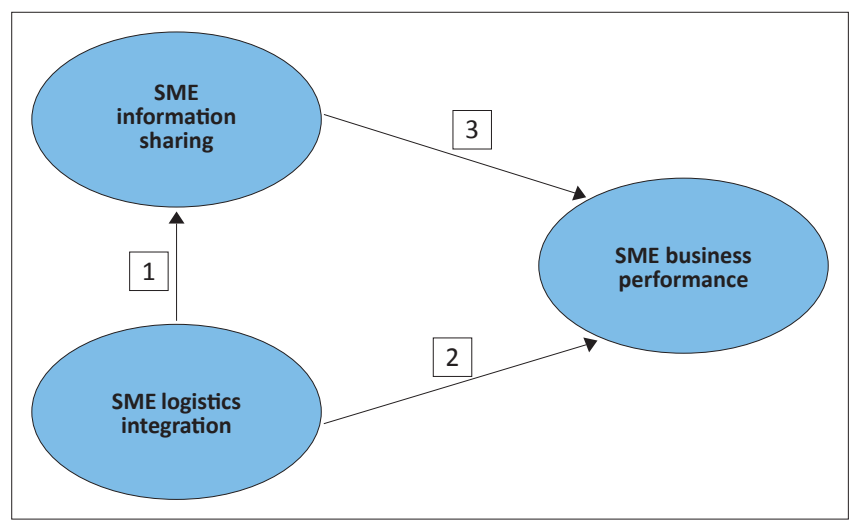

SME, small and medium enterprise.

FIGURE 1: Conceptual research model. 
in the case of SMEs. Therefore, drawing from the foregoing discussion, the following hypothesis is posited:

Hypothesis 2: SMEs logistics integration positively influences their business performance.

SME information sharing and business performance: Drawing from previous studies, information sharing amongst supply chain partners has a significant consequential impact on the effectiveness of business performance (Madlberger 2009). Information sharing also allows firms to make better decisions on ordering, capacity allocations, production and material planning through increased visibility of demand, supply and inventory (Lin, Huang \& Lin 2002; Iyer, Germain \& Claycomb 2009). Furthermore, many studies have indicated information sharing to be a key ingredient in achieving: increased coordination; reduced uncertainty; faster material flow; higher order fulfilment and shorter order cycle times; reduced inventory costs; increased customer satisfaction with fast and reliable delivery; (Soosay, Hyland \& Ferrer 2008). Some studies suggest that information sharing leads to improved business performance through its role as the driver of competitiveness and supply chain effectiveness (Forslund \& Jonsson 2007). Accordingly, in the context of this study, it is submitted that logistics integration enables SMEs to attain timely and accurate information (Iyer et al. 2009). Eventually, this in turn creates superior customer value for the SMEs' long-term survival and success within the supply chain context (Premus \& Sanders 2010). It can therefore be postulated that the higher the level of information sharing by the SMEs, the higher the expected level of business performance. Prior empirical evidence from large firms has found a positive relationship between information sharing and business performance (Forslund \& Jonsson 2007). Hence this study seeks to determine such a relationship in the case of SMEs. Therefore it can be postulated that:

Hypothesis 3: SMEs information sharing positively influences their business performance.

\section{Research methodology \\ Sample and data collection}

The data for this research was collected from SMEs in the Gauteng province of South Africa. The database of the SMEs (small businesses) was obtained from the Gauteng Enterprise Propeller and formed the research-sampling frame. A simple random probability sampling technique was used to obtain a sample size of 180 SMEs. Students from the Vaal University of Technology were recruited to distribute and collect the questionnaires after appointments with target small businesses were made by telephone. Of the total of 180 questionnaires distributed, 151 usable questionnaires were retrieved for the final data analysis, representing a response rate of $83.8 \%$.

\section{Measurement instrument and questionnaire design}

Research scales were designed on the basis of previous work. Proper modifications were made in order to fit the current research context and purpose. 'Logistics integration' was measured using six-item scales adapted from Chen and Paulraj (2004), whilst 'information sharing' used a five-item scale measure; all were adapted from Li, Ragu-Nathan, Ragu-Nathan and Rao (2006). Small business performance was measured using a four-item scale, which was adopted from Rivard, Raymond and Verreault (2006) and Merrilis, Rundle-Thiele and Lye (2011). All were measured on a fivepoint Likert-type scale that was anchored by 1 (strongly disagree) to 5 (strongly agree) in order to express the degree of agreement. Appendix A provides a list of all the measurement instruments used in this study.

\section{Respondent profile}

The questionnaire was in English and research assistants were trained to explain and clarify any queries regarding the questionnaire to the respondents. In order to eliminate missing entries, data cleansing was done before descriptive analysis using the Statistical Package for Social Sciences (SPSS) software. Table 1 presents the profile of the participants. The profile indicates that about three-quarters of the participating small businesses employ 50 workers or less $(76.8 \%)$, whilst less than a quarter have a workforce greater than 50 employees (23.2\%). More than half of the participants had less than five years working experience (59.6\%), more than a quarter of the participants had between five and ten years working experience $(33.8 \%)$, and less than a quarter had above ten years working experience (6.6\%). The study also indicated that the majority of the participants belonged to the service sector $(59.6 \%)$, whilst the manufacturing sector occupied the remainder of the percentages.

\section{Data analysis}

\section{Structural equation modeling approach}

In order to statistically analyse the measurement and structural models, this study used Smart PLS (Beta, Hamburg) software for the Structural Equation Modelling (SEM) technique (Ringle, Wende \& Will 2005). In SEM, the measurement model refers to the links between the latent variables and their manifest variables, and the structural model captures the hypothesised causal relationships

TABLE 1: Sample profile characteristics.

\begin{tabular}{lll}
\hline Characteristics & Frequency & $\%$ \\
\hline Number of employees & & \\
$\leqq 20$ & 76 & 50.3 \\
$21-50$ & 40 & 26.5 \\
$\geqq 51$ & 35 & 23.2 \\
Total & 151 & 100 \\
Participants working experience & & \\
$\leqq 5$ years & 90 & 59.6 \\
5-10 years & 51 & 33.8 \\
$\geqq 10$ years & 10 & 6.6 \\
Total & 151 & 100 \\
Industry & & \\
Manufacturing & 61 & 40.4 \\
Service & 90 & 59.6 \\
Total & 151 & 100 \\
\hline
\end{tabular}


TABLE 2: Accuracy analysis statistics.

\begin{tabular}{|c|c|c|c|c|c|c|c|}
\hline Research construct & LV index value & $R$-Squared value & Cronbach's $\alpha$ value & C.R. value & AVE value & Communality & Factor loading \\
\hline SBLI & 4.312 & 0.000 & 0.873 & 0.934 & 0.706 & 0.664 & - \\
\hline SBLI 1 & - & - & - & - & - & - & 0.685 \\
\hline SBLI 2 & - & - & - & - & - & - & 0.833 \\
\hline SBLI 3 & - & - & - & - & - & - & 0.887 \\
\hline SBLI 4 & - & - & - & - & - & - & 0.786 \\
\hline SBLI 5 & - & - & - & - & - & - & 0.931 \\
\hline SBLI 6 & - & - & - & - & - & - & 0.864 \\
\hline SBIS & 4.462 & 0.252 & 0.915 & 0.908 & 0.664 & 0.706 & - \\
\hline SBIS 1 & - & - & - & - & - & - & 0.830 \\
\hline SBIS 2 & - & - & - & - & - & - & 0.864 \\
\hline SBIS 3 & - & - & - & - & - & - & 0.839 \\
\hline SBIS 4 & - & - & - & - & - & - & 0.763 \\
\hline SBIS 5 & - & - & - & - & - & - & 0.773 \\
\hline SBP & 4.4346 & 0.552 & 0.837 & 0.892 & 0.676 & 0.676 & - \\
\hline SBP 2 & - & - & - & - & - & - & 0.910 \\
\hline SBP 3 & - & - & - & - & - & - & 0.883 \\
\hline SBP 4 & - & - & - & - & - & - & 0.661 \\
\hline
\end{tabular}

Note: Scores: 1 = Strongly disagree; $3=$ Neutral; $5=$ Strongly agree

C.R., Composite reliability; AVE, Average variance reliability; SBLI, Small business logistics integration; SBIS, Small business information sharing; SBP, Small business performance.

amongst the research constructs (Chin \& Newsted 1999). Unlike AMOS (IBM, USA) and LISREL (Scientific Software, Mooresville, USA), which are covariance-based approaches, Smart PLS is a regression-based technique that originates from path analysis. Smart PLS has emerged as a powerful approach to studying causal models involving multiple constructs with multiple indicators (Chinomona 2013). Smart PLS, a component-based method, has an ability to model latent constructs that are uncontaminated by measurement error under conditions of non-normality. It has the ability to handle complex predictive models in small-to-medium sample sizes. Since the current study sample size was relatively small (151), Smart PLS was found to be more appropriate and befitting the purpose of the current study. In this respect, the Bootstrapping-resampling method was used to test the statistical significance of the relationships. This procedure entailed generating 200 sub-samples of cases randomly selected, with replacement, from the original data. Table 2 presents evidence on the reliability and validity of the measurement model.

\section{Measurement model}

To ensure convergent validity, the researchers checked the items loaded on their respective constructs had loadings of greater than 0.6. On the other hand, discriminant validity was determined by ensuring that there were no significant inter-research variables cross-loadings (Chin 1998). As can be seen in Table 2, all items have loadings greater than 0.6 (ranging from $0.661-0.910$ ), with no cross-loadings greater than 0.728 , whilst $t$-statistics derived from bootstrapping (300 resamples) suggest that all loadings are significant at $\mathrm{pb}$ 0.001. As such, this confirms that all the measurement items converged well on their respective constructs and therefore are acceptable measures.

According to Chin (1998), research variables should have an average variance extracted (AVE) of more than 0.5 and a
TABLE 3: Correlations between constructs.

\begin{tabular}{llll}
\hline Research constructs & SBLI & SBIS & SBP \\
\hline Small business logistics integration & 1.000 & - & - \\
Small business information sharing & 0.502 & 1.000 & - \\
Small business performance & 0.728 & 0.704 & 1.000 \\
\hline
\end{tabular}

SBLI, small business logistics integration; SBIS, small business information sharing; SBP, small business performance

composite reliability of more than 0.7 (convergent validity), and inter-construct correlations should be less than the square-root of the AVE (discriminant validity). As can be seen in Table 2, all constructs exceed these criteria, with AVE and composite reliability (CR) generally equal or greater than 0.6 and 0.9 , respectively. Furthermore, as indicated in Table 3 , the square root of the lowest AVE is 0.82 and is greater than the highest inter-construct correlation value (0.787). These results confirm the existence of discriminant validity of the measurement used in this study.

\section{Path model}

PLS also generates the path coefficients for the relationships modelled amongst the constructs. The significance of these coefficients was assessed using the bootstrap procedure (with 300 sub-samples) that provided the $t$-values for each path estimate. Figure 2 and Table 4 present the results of the PLS analysis on the structural model along with the path estimates and $t$-values. Support for the study hypotheses, which are labelled on their corresponding paths in Figure 2, could be ascertained by examining the directionality (positive or negative) of the path coefficients and the significance of the $t$-values. The standardised path coefficients are expected to be at least 0.2 and preferably greater than 0.3 (Chin 1998).

The results are revealed in Figure 2, which presents the impact of small business logistics integration (SBLI) on small business information sharing (SBIS) and small business performance (SBP), and the relationship between SBIS and 


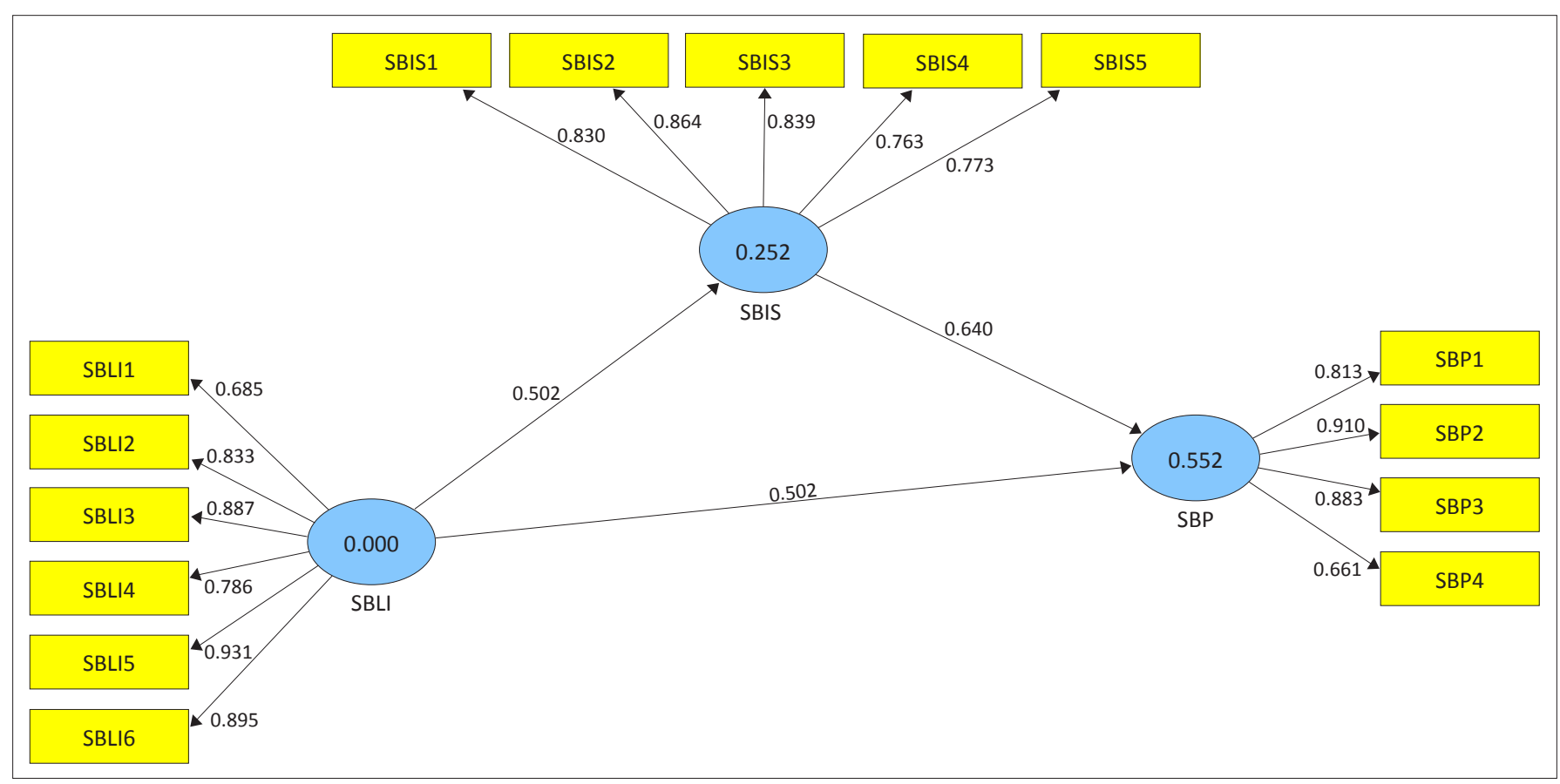

SBLI, small business logistics integration; SBIS, small business information sharing; SBP, small business performance.

FIGURE 2: Measurement and structural model results.

TABLE 4: Results of structural equation model analysis.

\begin{tabular}{|c|c|c|c|c|c|}
\hline Proposed hypothesis relationship & Hypothesis & Path coefficients & $t$-statistics & Rejected & Supported \\
\hline $\begin{array}{l}\text { Small business logistics integration (SBLI) } \\
\downarrow \\
\text { Small business information sharing (SBIS) }\end{array}$ & 1 & 0.502 & 7.475 & no & yes \\
\hline $\begin{array}{l}\text { Small business information sharing (SBIS) } \\
\downarrow \\
\downarrow \\
\text { Small business performance (SBP) }\end{array}$ & 3 & 0.640 & 10.671 & no & yes \\
\hline
\end{tabular}

SBP. As posited in the current study, Figure 2 indicates that SBLI has a positive influence on SBIS $(\beta=0.502, t=7.475)$, thus supporting Hypothesis 1. Regarding the impact of SBLI on SBP, the results show that SBLI has a positive relation with SBP $(\beta=0.174, t=2.168)$, thus Hypothesis 2 was supported. The results also demonstrate that SBP is also positively influenced by SBIS $(\beta=0.640, t=10.671)$, therefore, supporting Hypothesis 3. Premised on the current research findings, support for all three hypotheses is provided, resulting in a positive triangular relationship between SBLI, SBIS and SBP.

The $R^{2}$ values for the two dependent variables (SBIS and SBP) are 0.252 and 0.552 respectively. These results reveal that SBIS explains the $25.2 \%$ of the variance in small business information sharing, hence suggesting that other variables that were not considered in this research may also be associated with small business information sharing across the supply chain. However, the results for small business performance indicate that small business logistics integration and small business information sharing together explain the $55.2 \%$ variance in small business performance.

Following formulae provided by Tenenhaus et al. (2005), the calculated global goodness-of-fit (GoF) statistic for the research model is 0.374 , which exceeds the threshold of GoF > 0.36 suggested by Wetzels, Odekerken-Schröder and Van Oppen (2009). Thus, this study concludes that the research model has a good overall fit.

\section{Discussion and conclusion}

The purpose of this study was to investigate the influence of small business logistics integration on small business information sharing and small business performance. In particular, three hypotheses were postulated. To test the proposed hypotheses, data were collected from small businesses in South Africa. The empirical results supported all three proposed research hypotheses in a significant way.

It is important to note from the study findings that small business logistics integration has stronger effects on small business information sharing (0.502) than on small business performance (0.174). Notably too, the relationship between small business information sharing and small business performance is robust (0.640). By implication, this finding indicates that small business logistics integration has a strong influence on small business performance via small business information sharing. Perhaps this could be due to the fact that timely and accurate sharing of strategic information can 
foster the reduction of unwarranted wastages and costs in a supply chain, hence leading to increased SME profitability.

\section{Implications of the study}

The ever-increasing importance of South African SME logistics integration on performance cannot be over-emphasised. In particular, the efficacy of supply chains might be difficult to achieve without logistics integration. The current study is an attempt to undertake research in a commonly neglected, yet important, sector of the South African economy. Therefore, the findings of this empirical study are expected to provide fruitful implications to both practitioners and academics.

On the academic side, this study makes a significant contribution to the SMEs performance literature by systematically exploring the impact of logistics integration on information sharing and business performance in the context of South African small businesses. In particular, the current study's findings provide tentative support to the proposition that logistics integration should be recognised as a significant antecedent and tool to foster information sharing and business performance in the SME sector.

On the practitioners' side, the important influential role of logistics integration and information sharing on business performance in Gauteng Province's SME sector is highlighted. This study therefore submits that in order to enhance their business performance. SMEs should integrate their logistics activities and ensure that they share vital business information The understanding is, that when the SMEs logistics activities are integrated with those of their supply chain partners, there is likely to be an accurate and timely exchange of important business information, a reduction in risks and costs in the process and therefore a consequent improvement in business performance. Furthermore, given the robust relationship between information sharing and business performance, SME owners and managers need to invest in an information-sharing infrastructure, such as information technology (IT), in order to facilitate timeous exchanges of vital business information. Vibrant information sharing between supply chain partners tends to foster the building of trust and long-term relationships with suppliers and customers within supply chains. Eventually, trust and long-term relationships are beneficial to supply chain partners since they are reported in the extant literature to result in improved business performance (Premus \& Sanders 2010; Renko \& Ficko 2010; Olhager \& Prajogo 2012).

\section{Imitations and future research}

Although this study makes significant contributions to both academia and practice, it was limited in some ways, and therefore some future research directions are suggested. Firstly, the data were only gathered from the SMEs in the Gauteng Province of South Africa. Perhaps the results would be more informative if data from SMEs in other provinces of the country were also included. Future studies may therefore be conducted by using data from other SMEs across the country. Secondly, the current study was limited to SMEs in South Africa. Subsequent research should contemplate replicating this study in other developing countries in Africa to enable result comparisons. Future studies could also extend the current study's conceptual framework by studying the effects of a larger set of variables. For instance, the influence of strategic networks on logistics integration could be investigated. This will immensely contribute new knowledge to the existing body of logistics and supply chain management literature on small business in developing countries, which is a neglected research field.

\section{Acknowledgements Competing interests}

The authors declare that they have no financial or personal relationship(s) that may have inappropriately influenced them in writing this article.

\section{References}

Abor, J. \& Quartey, A., 2010, 'Issues in SME development in Ghana and South Africa', International Research Journal of Finance and Economics 39(6), 215-228.

Ambe, I.M., 2012, 'Determining an optimal supply chain strategy', Journal of Transport and Supply Chain Management 6, 126-147.

Arminas, D., 1999, 'Sainsbury's Targets SMEs for EDI', Supply Management 4(3), 1012.

Ansari, A., Lockwood, D.L. \& Modarress, B., 1999, 'Supplier Product Integration in a New Competitive Approach', Production and Inventory Management Journal 40(3), 57-61.

Bagchi, P. \& Skjoett-Larsen, T., 2003, 'Integration of information technology and organizations in a supply chain', International Journal of Logistics Management 14(1), 89-108. http://dx.doi.org/10.1108/09574090310806477

Ballou, R.H., 2007, 'The evolution and future of logistics and supply chain management', European Business Review 19(4), 332-348. http://dx.doi. management', European Business

Chen, I.J. \& Paulraj, A., 2004, 'Towards a theory of supply chain management: The constructs and measurements', Journal of Operations Management 22(2), 11950. http://dx.doi.org/10.1016/j.jom.2003.12.007

Chin, W.W., 1998, 'Issues and opinions on structural equation modeling', MIS Quarterly 22(1), 7-16.

Chin, W. \& Newsted, P.R., 1999, 'Structural equation modeling analysis with small samples using partial least squares', in R. Hoyle (ed.), Statistical Strategies for Small Sample Research, Sage, Thousand Oaks, CA, 307-41.

Chinomona, R., 2012, 'The influence of dealers' referent power and legitimate power in Guanxi distribution networks: The case of Taiwan's SME firms', African Journal of Business Management 6(37), 10125-10137. http://dx.doi.org/10.5897/ AJBM11.1494

Chinomona, R., Lin, J., Wang, M. \& Cheng, J., 2010, 'Soft power and desirable relationship outcomes in 'Zimbabwe distribution channels', African Journal of Business 11(2), 20-55.

Chinomona, R. \& Pretorius, M., 2011, 'SME manufacturers' cooperation and dependence on major dealers' expert power in distribution channels', South

Chinomona, R., 2013, 'Information technology resource as a facilitator of suppliers' collaborative communication, network governance and relationship longevity in collaborative communication, network governance and relationship longevity in
supply chains', Journal of Transport and Supply Chain Management 7(1), 1-10. supply chains', Journal of Transport and
http://dx.doi.org/10.4102/jtscm.v7i1.83

Chinomona, R. \& Cheng, J.M-S., 2013, 'Distribution channel relational cohesion exchange model: A Small-to-Medium Enterprise manufacturer's perspective', Journal of Small Business Management 51(2), 256-275. http://dx.doi. org/10.1111/jsbm.12011

Choi, K., Narasimhan, R. \& Kim, S.W., 2011, 'Postponement strategy for international transfer of products in a global supply chain: A system dynamics examination', Journal of Operations Management 30, 167-179. http://dx.doi.org/10.1016/j. jom.2012.01.003

Coyle, J.J., Bardi, E.J., \& Langley, C.J., 2003, The management of business logistics: A supply chain perspective, 7th edn., South-Western Publishing Company, MN.

Cusumano, M.A., Yoffie, B., 1998, Competing on Internet Time: Lessons from Netscape and its battle with Microsoft, Free Press, New York. PMCid:PMC22575

Daugherty, P.J., Ellinger, A.E. \& Gustin, C.M., 1996, 'Integrated logistics: Achieving logistics performance improvements', Supply Chain Management: An International Journal 1(3), 25-33. http://dx.doi.org/10.1108/13598549610155297

Erasmus, A.C. \& Mathunjwa, G.Q., 2013, 'Idiosyncratic use of credit facilities by consumers in an emerging economy', International Journal of Consumer Studies 35(3), 359-371. http://dx.doi.org/10.1111/j.1470-6431.2010.00946.x 
Fatoki, O. \& Garwe, D., 2010, 'Obstacles to the growth of new SMEs in South Africa: A principal component analysis approach', African Journal of Business Management principal compone
$4(5), 729-738$.

Flynn, B.B., Huo, B. \& Zhao, X., 2010, 'The impact of supply chain integration on performance: A contingency and configuration approach', Journal of Operations Management 28(1), 58-71. http://dx.doi.org/10.1016/j.jom.2009.06.001

Forslund, H. \& Jonsson, P., 2007, 'The impact of forecast information quality on supply chain performance', International Journal of Operations \& Production Management 27(1), 90-107. http://dx.doi.org/10.1108/01443570710714556

Gelinas, R. \& Bigras, Y., 2004, 'The characteristics and features of SMEs: Favorable or unfavorable to logistics integration?', Journal of Small Business Management 42(3), 263-278. http://dx.doi.org/10.1111/j.1540-627X.2004.00111.x

Gimenez, C., 2006, 'Logistics integration processes in the food industry', International Journal of Physical Distribution \& Logistics Management 36(3), 231-249. http:// dx.doi.org/10.1108/09600030610661813

Green Jr, K.W., Whitten, D. \& Irnam, R.A., 2008, 'The impact of logistics performance in a supply chain context', Supply Chain Management: An International Journal 13(4), 317-347. http://dx.doi.org/10.1108/13598540810882206

Häkkinen, L., Norrman, A., Hilmola, O. \& Ojala, L., 2004, 'Logistics Integration in Horizontal Mergers and Acquisitions', International Journal of Logistics Management 15(1), 27-42. http://dx.doi.org/10.1108/09574090410700211

Handfield, R.B. \& Pannesi, R.T., 1992, 'An empirical study of delivery speed and reliability', International Journal of Operations and Production Management, 12(16), 60-74. PMid:7575864

Handfield, R.B., 1995, Re-engineering for Time-based Competition-Benchmarks and Best Practices for Production, $R \& D$, and Purchasing, Quorum Books, Westport/ CT, London. http://dx.doi.org/10.1080/00207549508930163

Handfield, R.B., \& Pannesi, R.T., 1995, 'Antecedents of lead-time competitiveness in make-to-order manufacturing firms', International Journal of Production Research make-to-order man.

Hendrick, T.E., 1994, Purchasing's contributions to time-based strategies, Center for Advanced Purchasing Studies, Tempe, AZ.

Homburg, C., \& Pflesser, C., 2003, 'A multiple-layer model of market-orientated organizational culture: Measurement issues and performance outcomes' Journal of
Marketing Research 37, 449-462. http://dx.doi.org/10.1509/jmkr.37.4.449.18786

Hooley, G.I., Greenley, G.E., Cadogan, J.W. \& Fahy, J., 2005, 'The performance impact of marketing resources', Journal of Business Research, 58(1), 18-27. http://dx.doi. org/10.1016/S0148-2963(03)00109-7

Iyer, K.N.S., Germain, R. \& Claycomb, C., 2009, 'B2B e-commerce supply chain integration and performance: A contingency fit perspective on the role of environment', Information and Management 46, 313-322. http://dx.doi. org/10.1016/j.im.2009.06.002

Jayaram, S., Jayaram, U., \& Wanet, Y., 1999, 'A Virtual Assembly Design Environment,' Proc. IEEE Virtual Reality 99 Conf., IEEE CS Press, Los Alamitos, Calif., pp. 172-179.

Kannan, V.R. \& Tan, K.C., 2005, 'Just in time, total quality management, and supply chain management: Understanding their linkages and impact on business performance', Omega: The International Journal of Management Science 33(2), 153-62. http://dx.doi.org/10.1016/j.omega.2004.03.012

Kathuria, R., 2000, 'Competitive priorities and managerial performance: A taxonomy of small manufacturers', Journal of Operations Management 18, 627-641. http:// dx.doi.org/10.1016/S0272-6963(00)00042-5

Kim, S.W., 2006, 'Effects of supply chain management practices, integration and competition capability on performance', Supply Chain Management: An International Journal 11(3), 241-248.

Kim, S.W., 2009, 'An Investigation on the Direct and Indirect Effect of Supply Chain Integration on Firm Performance', International Journal of Production Economics 119, 328-46. http://dx.doi.org/10.1016/j.ijpe.2009.03.007

Lai, K.H., Ngai, E.W.T. \& Cheng, T.C.E., 2004, 'An empirical study of supply chain performance in transport logistics', International Journal Production Economics performance in transport logistics', International Journal Prod
$87,321-331$. http://dx.doi.org/10.1016/j.ijpe.2003.08.002

Lai, K.H., Wong, C.W.Y. \& Cheng, T.C.E., 2010, 'Bundling digitized logistics activities and its performance implications', Industrial Marketing Management 39(2), 273-286. its performance implications', Industrial Marketing Man
http://dx.doi.org/10.1016/j.indmarman.2008.08.002

Lee, C.W., Kwon, I-K. \& Severance, D., 2007, 'Relationship between supply chain performance and degree of linkage amongst supplier, internal integration, and customer', Supply Chain Management: An International Journal 12(6), 444-452.

Li, S., Ragu-Nathan, B., Ragu-Nathan, T.S. \& Rao, S.S., 2006, 'The impact of supply chain management practices on competitive advantage and organizational performance', Omega 34, 107-124. http://dx.doi.org/10.1016/j.omega.2004.08.002

Lin, F., Huang, S. \& Lin, S., 2002, 'Effects of information sharing on supply chain performance in electronic commerce', IEEE Transactions on Engineering Management 49(3), 258-68. http://dx.doi.org/10.1109/TEM.2002.803388

Louw, L. \& Venter, P., 2006, Strategic Management: Winning in the Southern African Workplace, Oxford University Press, Cape Town.

Madlberger, M., 2009, 'What Drives Firms to Engage in Interorganizational Information Sharing In Supply Chain Management', International Journal of e-Collaboration Sharing In Supply Chain Management', International Jour
5(2), 18-42. http://dx.doi.org/10.4018/jec.2009040102

Merrilees, B., Rundle-Thiele, S. \& Lye, A., 2011, 'Marketing capabilities: Antecedents and implications for B2B SME performance', Industrial Marketing Management 40(20), 368-375. http://dx.doi.org/10.1016/j.indmarman.2010.08.005
Olhager, J. \& Prajogo, D., 2012, 'The impact of manufacturing and supply chain improvement initiatives: A survey comparing make-to-order and make-to-stock improvement initiatives: A survey comparing make-to-order and make-to-stoc
firms', Omega 40, 159-165. http://dx.doi.org/10.1016/j.omega.2011.05.001

O'Leary-Kelly, S.W. \& Flores, B.E., 2002, 'The integration of manufacturing and marketing/sales decisions: Impact on organizational performance', Journal of Operations Management 20(3), 221. http://dx.doi.org/10.1016/s0272of Operations (02)00005-0

Pagel, M., 2004, 'Understanding the factors that enable and inhibit the integration of operations, purchasing and logistics', Journal of Operations Management 22, 459-487. http://dx.doi.org/10.1016/j.jom.2004.05.008

Prajogo, D. \& Olhager, J., 2012, 'Supply chain integration and performance: The effects of long-term relationships, information technology and sharing, and logistics integration', International Journal of Production Economics 135(1), 514-522. http://dx.doi.org/10.1016/j.ijpe.2011.09.001

Premus, R. \& Sanders, N.R., 2010, 'Information sharing in global supply chain alliances', Journal of Asia-Pacific Business 9(2), 174-92. http://dx.doi. org/10.1080/10599230801981928

Renko, S. \& Ficko, D., 2010, 'New logistics technologies in improving customer value in retailing service', Journal of Retailing and Consumer Services 17, 216-223. http:// dx.doi.org/10.1016/j.jretconser.2010.03.012

Republic of South Africa (RSA), 2003, National Small Business Amendment Act, viewed 05 February 2013, from http://www.info.gov.za/gazette/acts/2003/a26-03/pdf

Richardson, H.L., 1995, 'Logistics help for the challenged', Transportation and Distribution, January, 60-64.

Richardson, H.L., 1999, 'Inventory: Big Numbers Meant Increased Attention, Transportation and Distribution 40(9), 88-96.

Rivard, S., Raymond, L. \& Verreault, D., 2006, 'Resource-based view and competitive strategy: An integrated model of the contribution of information technology to firm performance', Journal of Strategic Information Systems 15, 29-50. http:// dx.doi.org/10.1016/j.jsis.2005.06.003

Roth, A.V. \& Miller, J.G., 1990, 'Manufacturing Strategy, Manufacturing Strength Managerial Success, and Economic Outcomes,' In J. Ettlie, M. C. Burstein and A. Fiegenbaum (Eds.), Manufacturing Strategies, Kluwer Academic Publishers, Boston, MA, 97-108. http://dx.doi.org/10.1007/978-94-009-2189-4_11, PMid:2363911

Rutner, S.M. \& Langley Jr, J., 2000, 'Logistics Value: Definition, Process and Measurement', The International Journal of Logistics Management 11(2), 73-82.

Sahin, F. \& Robinson Jr, E.P., 2005, 'Information sharing and coordination in make-toorder supply chains', Journal of Operations Management 23(6), 579-98. http:// dx.doi.org/10.1016/j.jom.2004.08.007

Safizadeh, H.M., Ritzman, L.P., Sharma, D. \& Wood, C., 1996, 'An empirical analysis of the product-process matrix', Management Science 42(11), 1576-1591. http:// of the product-process matrix', Manci.
dx.doi.org $/ 10.1287 / \mathrm{mnsc} .42 .11 .1576$

Shin, H., Collier, D.A. \& Wilson, D.D., 2000, 'Supply management orientation and supplier/buyer performance', Journal of Operations Management 18, 317-333. $\mathrm{http}: / / \mathrm{dx}$.doi.org/10.1016/S0272-6963(99)00031-5

Soosay, C.S., Hyland, P.W. \& Ferrer, M., 2008, 'Supply chain collaboration: Capabilities for continuous innovation', Supply Chain Management: An International Journal 13(2), 160-169.

Tenenhaus, M., Vinzi, V.E., Chatelin, Y.M. \& Lauro, C., 2005, 'PLS Path Modeling', Computational Statistics and Data Analysis 48(1), 159-205. http://dx.doi. org/10.1016/j.csda.2004.03.005

Quesada, G., Rachamadugu, R., Gonzalez, M. \& Martinez, J.L., 2008, 'Linking order winning and external supply chain integration strategies', Supply Chain Management: An International Journal 13(4), 296-303.

Van der Vaart, T. \& Van Donk, D.P., 2008, 'A critical review of survey-based research in supply chain integration', International Journal of Production Economics 111 42-55. http://dx.doi.org/10.1016/j.ijpe.2006.10.011

Vickery, S.K., Droge, C., Yeomans, J.M. \& Markland, R.E., 1995, 'Time-based competition in the furniture industry: An empirical study', Production and Inventory Management Journal 36(4), 14-21.

Vorhies, D.W. \& Morgan, N.A., 2005, 'Benchmarking marketing capabilities for sustained competitive advantage', Journal of Marketing 69(1), 80-94. http:// dx.doi.org/10.1509/jmkg.69.1.80.55505

Welch, J. F., Bossidy, L.A. \& Hood, E.E., 1990, 'To our Shareholders', General Electric 1990 Annual Report, 1-4.

Wetzels, M., Odekerken-Schröder, G. \& Van Oppen, C., 2009, 'Using PLS path modeling for assessing hierarchical construct models: Guidelines and empirical illustration' Management of Information Science Quarterly.

Wong, H. \& Merrilees, B., 2007, 'Multiple roles for branding in international marketing', International Marketing Review 24(4), 384-408. http://dx.doi. marketing', International Marketing
org/10.1108/02651330710760982

Zailani, S. \& Rajagopal, P., 2005, 'Supply chain integration and performance: US versus East Asian companies', Supply Chain Management: An International Journal 10(5), 379-93.

Zhou, H. \& Benton, W.C., 2007, 'Supply Chain Practice and Information Sharing', Journal of Operations Managements 25, 1348-65. http://dx.doi.org/10.1016/j. jom.2007.01.009 


\section{Appendix A: Measurement instruments \\ Logistics integration}

- Inter-organisational logistic activities are closely coordinated.

- Our logistics activities are well integrated with the logistics activities of our suppliers.

- We have a seamless integration of logistics activities with our key suppliers.

- Our logistics integration is characterised by excellent distribution, transportation and/or warehousing facilities.

- The inbound and outbound distribution of goods with our suppliers is well integrated.

- Information and materials flow smoothly between our supplier firms and us.

\section{Information sharing}

- We inform our trading partners in advance of changing needs.

- Our trading partners share proprietary information with us.

- Our trading partners keep us fully informed about issues that affect our business.

- Our trading partners and we exchange information that helps in the establishment of business planning.

- Our trading partners and we keep each other informed about events or changes that may affect the other partners.

\section{Small business performance}

- Our firm has stronger growth in sales revenue.

- Our firm is better able to acquire new customers.

- Our firm has a greater market share.

- Our firm is able to increase sales to existing customers. 